\section{Bran Nue Dae: an essentially \\ conservative work sacrificing \\ politics for a Utopian \\ reconciliation?}

\section{By Charlotte Salusinszky \\ University of Melbourne \\ undergraduate}

Jimmy Chi \& Kuckles (Musical group)

Bran Nue Dae: a musical journey

Currency Press, Magabala Books, 1991

ISBN: 0868192937

Bran Nue Dae, written by Jimmy Chi, directed by Andrew Ross, and with a score performed by Kuckles, uses the eccentricity of the musical theatre genre to communicate political messages in innovative and unexpected ways. Indeed, the play's origins are in Broome, a city that as Peter Bibby articulates in the script's introduction, ‘is such a long way from anywhere that it might as well be nowhere, which is perhaps a good starting point for surprises’ (Bibby 1991, p.6). Part of what characterises the text and makes it so surprising is its combination of non-naturalistic techniques and hard-hitting political statements. In this essay, I will first weigh up three separate issues; whether Bran Nue Dae can be considered conservative, the extent to which it is political, and the nature of its conclusion which, as the essay question suggests, presents a utopian reconciliation that compromises its political aims. Following this, I will assess the question as a whole, determining whether the musical's conclusion jars or aligns with the rest of the text. Ultimately, I will argue that although the musical theatre genre enables Bran Nue Dae to be blatant and outlandish, the political issues it explores are incorporated into the text in complex, subtle and oftentimes abstract ways.

At its core, Bran Nue Dae has an eccentric, batty and vibrant personality, crafted by actors and musicians who chose to express this character in ways that do not align with traditional theatrical structures. As a result, Chi 
makes the piece available for interpretation by a diverse range of audiences, not just regular theatre-goers who are familiar with the form's conventions. The play toured interstate including, as Bibby explains, a performance in an Aboriginal community at Kalumburu where it 'came to its roots' (Bibby 1991, p.8) on a school lawn with a stage marked out with flour. This reflects how easily the production functions outside of a traditional theatre setting where a barrier, a fourth-wall, divides the audience and the actors. The musical does not have a strict linear and coherent narrative; instead, it deviates and indulges in non-naturalistic moments. Willie and Rosie are 'transported into the movie' (Chi 1991, p.2), Benedictus appears onstage 'in a cloud of smoke' (p.4) and wearing a 'black cassock embroidered with Cherry Ripe bars' (p.4), and Willie with his fellow travelers is gaoled in one scene and inexplicably back on the road in the next (p.41). At one point in the play the audience is thrown condoms (Chi 1991, p.75), and in another Cherry Ripe bars (p.87). Bran Nue Dae demonstrates a non-conservative approach to theatremaking in the imaginative ways in which it confidently deviates from traditional narrative structures and verges on the surreal.

The text and ideas that Bran Nue Dae grapples with also are not conservative, though these are often conveyed through euphemism, song and humour in order to destigmatise controversial issues for the audience. The song, Seeds That You Might Sow, exemplifies this approach because underneath the bawdy humour and sexual innuendos such as, 'I like your polony or perhaps a sausage roll' (Chi 1991, p.73), Chi has claimed that here he advocates the use of condoms as a protection against contracting sexually transmitted diseases (Bran Nue Dae 3 1991). The women warning the men that they 'cannot pook my hole’ (Chi 1991, p.73), is an example of Chi's desire to 'address the issue through humour and the means of music' (Bran Nue Dae 3 1991), instead of through didacticism. Considering that the play was written just after the 1980s when AIDS emerged, provoking hysteria and backlash 
particularly towards the homosexual community, their decision to address the issue in a satirical way would have presumably destigmatised the disease for the audience. The play blends outlandish eccentricity with uncompromising bluntness to disarm audiences, allowing issues that would otherwise make some people feel confronted to be explored in productive ways.

However, this lively and upbeat approach to tackling political issues is certainly not infallible. The treatment of women in the text, particularly the character of Rosie, is an example of how Bran Nue Dae at times compromises political issues seemingly for the sake of a comedic romp. Rosie is only ever viewed from the perspective of male desire, sexualising her before she even utters her first words of dialogue. Soon after Rosie enters the first scene of the play, Lucy calls out to her, 'Hey Rosie, he wanna sit wit you!' (Chi 1991, p.1) and, as the other teenagers continue to tease her, Rosie is humiliated and 'works her way in embarrassment to centre stage' (p.2). This pattern is continued when Willie and Rosie are later reunited in the Branding Iron Bar asTadpole discusses with Willie which of them will 'have a go’ (Chi 1991, p.54) with her. Tadpole advises Willie that, 'when man find a woman you gotta make love to them' (Chi 1991, p.46), repeatedly encouraging him to 'go grab 'em' (p.48) and demonstrating how to 'grab tarts in this country’ (p.56). Although these remarks are probably intended to be humourous, provide greater insight into Tadpole's personality and allow him to bond with Willie, Chi does not offer any contrasting view that counteracts this sexualised one. In doing so, he alienates female audience members and sacrifices an opportunity to offer a more productive alternative to this portrayal of interactions between men and women.

This issue is furthered when considering that Rosie's agency in the text is sacrificed for the sake of Willie's coming of age story. Perhaps the climax of his journey occurs when he discovers that Tadpole is actually his father. This revelation occurs just instants after he appears post-coital and naked in front of 
Tadpole, Marijuana Annie, Slippery and Theresa to declare that 'I'm a man now' (Chi 1991, p.76). By pairing these two discoveries together, Chi attributes equal value to Willie's sexual encounter as he does to Willie's reunion with his father. Strangely, Rosie does not appear with him at this time, neither naked nor clothed. As a result, attention is focussed on Willie and the culmination of his journey at the expense of addressing Rosie's experience of their intimacy. However, Chi has pointed out that there is an insidious and widespread paradigm of viewing Aboriginals as 'innocent little children that need to be cared for' (Bran Nue Dae 2 1991), rather than autonomous individuals with a diverse range of life experiences. These highly sexualised interactions that reoccur throughout the narrative can then also be interpreted as Chi's attempt to buck against this perception, intentionally rejecting the fulfillment Settler desires and expectations. It is also important to consider the roles of Marijuana Annie and Theresa in the text; while Annie's boyfriend was killed in Vietnam, prompting her to give away her baby,
Theresa was abandoned and her son taken by Benedictus. As problematic as the portrayal of women in Bran Nue Dae seem to be, Chi does depict a pretty grim depiction of womanhood which is in itself a potent political message to propagate.

The final scenes of Bran Nue Dae contain moments of revelation in which characters gain new information about or come to a greater acceptance of their past and heritage. These scenes are performed with a Pentecostal Christian worship service as a backdrop; as the congregation sings All The Way Jesus, Pastor Flakkon begins by announcing that 'tonight is the night of miracles' (Chi 1991, p.59). Due to the uncurbed Pentecostal charisma of this event and the way it is introduced into the play so unexpectedly, the audience is not encouraged to take this statement seriously. Though as the rest of the narrative unfolds, family members and past lovers are actually reunited in surprising ways as Pastor Flakkon predicted. Along with these discoveries comes an increased honesty between 
characters, as they express their regrets and troubles to each other. Benedictus and Theresa in particular reveal controversial stories from their past, demonstrating that all people are strikingly adept at hurting themselves and others regardless of their worldview. Interestingly, by these final scenes Tadpole's constant assertion throughout the play that 'I bin drinkin', I bin drovin' and I bin a Christian' (Chi 1991, p.70), stops seeming like a pontificating character trait. When compared to Benedictus' overtly sentimental musing that 'dere is no beginning and dere is no end in our long journey through life' (Chi 1991, p.84), Tadpole's blunt selfassessment voices a pragmatic and lessromanticised approach towards the inconsistencies and multiplicities of human behaviour, and the audience is encouraged to align themselves with this view. Indeed, there is a sense of hope and optimism that permeates the last scenes of the play as a disparate group of individuals becomes a makeshift community, however, this occurs as a reaction to the series of revelations and not through initiative or desire to achieve a sense of reconciliation.

Contrary to the idea that Bran Nue Dae finishes with a utopian reconciliation, I contend that Chi weaves a sinister undercurrent through these last scenes that dismantles an ideal resolution to the text. As previously discussed in this essay, the final scenes of Bran Nue Dae occur amongst a Pentecostal Christian gathering. Their introduction to the play begins with a rendition of All The Way Jesus that 'takes over and interrupts' (Chi 1991, p.59) one of Willie's genuinely tender moments with Rosie. Although the words 'cos I love you, I'll love you until there's...' (Chi 1991, p.58) are sung in English, Willie mostly uses an Aboriginal dialect to communicate with Rosie in this moment and, in doing so, reveals his thoughts and feelings exclusively to her and makes them unavailable to the audience members. However, this sense of emotional privacy and intimacy between them is suddenly trampled by the oncoming congregation. When Benedictus reappears in the narrative after an extended absence, he 
authoritatively aestheticises and interprets the situation even though he has not experienced the transformative journey that the travelers have. In response to the revelation that he was once romantically involved with Theresa and subsequently took their child and deserted her, he 'covers his embarrassment' (Chi 1991, p.83) and surmises that 've are all fallen angels and ve all haff a multitude of crosses to bear' (p.83). By speaking using the regal firstperson plural, Benedictus shirks individual responsibility for the longterm damage his actions caused and suggests that he can empathise with the Aboriginal characters when his experience wildly differs from theirs. It is problematic that it is Benedictus who has the final spoken words of the play, 'Absolvo Te' (Chi 1991, p.87), wielding the authority to forgive and pardon the other characters from the hurt they have experienced or inflicted in the past. In a text exploring the diverse experiences of Aboriginal people in Australia, Chi seemingly has chosen to hijack the trajectory of his own narrative with an ending that is anything but utopian.
So far in this essay, I have disputed the claim that Bran Nue Dae conservatively sacrifices dealing with important political issues and instead indulges in an unrealistic utopian reconciliation. I have explored how the musical form allows Chi to develop the script's themes in inventive and unexpected ways, and now assert that it also adds to an element of sarcasm that arises as the text progresses. On a surface level, the play’s ending seems reconciliatory as the cast sing together and 'assembles as in a portrait, with the various couples paired' (Chi 1991, p.89). However, as I discussed earlier, a bleak picture of continuing Settler invasion of the lives of Aboriginal people, dictating how their communities and individuals should interact, is actually in operation at this point. Consequentially, this cheery tableaux onstage begins to seem oddly sarcastic. I am interested in the reasons why Chi constructed his musical in this way, essentially sabotaging his own project and his own vision for the characters' futures. In a short interview about Bran Nue Dae he has explained that 'Aboriginal people are, you know, not 
exactly sort of liked or - let's face it, they're not liked' (Bran Nue Dae 1 1991); in response to this, the play's conclusion demonstrates just how Aboriginal autonomy is continually curtailed and monitored by paternalistic Settler authorities. In light of this, the end of a script supposedly focussing on acceptance and belonging actually has pulsing through it an exploration of what it means to be hated and exiled. Chi forces the audience to question whether what they are laughing at is truly funny, and whether the fulfillment of Settler desires is actually what they find heartwarming.

An interesting approach to interpreting Bran Nue Dae is through positioning it as a parable or fable. Chi himself has expressed that, 'The play is a parable. It's a wonderful thing. It says the naked truth is ugly. But when he's dressed in the fine clothes of the parable, then he becomes acceptable’ (Bran Nue Dae 1 1991). This technique is also in line with his use of humour and music to explore issues that would otherwise be considered confronting. An element of this parabolic approach to storytelling in Bran Nue Dae is the use of caricature to at times fondly satirise characters and their world views. Marijuana Annie, for example, is an extremely intricate character with a traumatic past but Chi still wryly parodies her free-spirited approach to life. She is baffled by anyone restricting her access to marijuana because, 'how do you think I'm supposed to keep my equilibrium and my social outlook together if I don’t have this little weed to help me get along?' (Chi 1991, p.30). She later scoffs at the police incarcerating her 'just because we're free spirits and we're trying to have a good time’ (Chi 1991, p.32). Similarly, her lover Slippery is genuinely caring and concerned, albeit naively, about the 'local people...coloured people...native people’ (Chi 1991, p.27). Both of them have a tendency to trivialise and aestheticise the life of Aboriginal communities; Slippery is enticed into partaking in their adventure by the prospect of 'passion in the tropics' (Chi 1991, p.26), and when they arrive in the Branding Iron Bar Marijuana Annie immediately declares 'wow, this is my kind of scene' (p.53). 
Considering the musical as a parable, these instances critique Annie and Slippery's practice of only pursuing the experiences that they find attractive in the lives of Aboriginal people in their chase of self-discovery. As a parable, Bran Nue Dae comically, tenderly and critically reveals the characters' search for meaning and identification.

Ultimately, I assert here that Bran Nue Dae is a parable within a parable in the form of a musical. Willie's coming-ofage narrative and growing friendship with Tadpole, along with the other journeys of self-discovery that many of the other characters in the text undergo, are whisked away by Benedictus' intrusion into the final segment of the text. This creates another parable on an even larger scale, enacting the distain and silencing of Aboriginal voices and histories in Australia. Combining this with musical conventions and a tendency to veer into surreal and unexpected sequences helps to keep the audience engaged and continually forces them to reposition themselves in relation to the text. Importantly, in musicals the songs, narrative and character tropes are extremely catchy and memorable; so we can rest assured that the issues Chi's text confronts are likely to become lodged in the memories of audiences members long after viewing.

\section{Reference List}

Bibby, P. 1991, Bran Nue Dae, Currency Press, Paddington.

Chi, J. 1991. Bran Nue Dae, Currency Press, Paddington.

Bran Nue Dae (Clip 1) 1991, audiovisual, Australian Screen, viewed 10 November 2014, $<$ http://aso.gov.au/titles/documentaries/bran-nue-dae/clip1/.>

Bran Nue Dae (Clip 2) 1991, audiovisual, Australian Screen, viewed 10 November 2014, http://aso.gov.au/titles/documentaries/bran-nue-dae/clip2/.>

Bran Nue Dae (Clip 3) 1991, audiovisual, Australian Screen, viewed 10 November 2014, http://aso.gov.au/titles/documentaries/bran-nue-dae/clip3/.> 